\title{
The Clacton Spear: The Last One Hundred Years
}

\section{U A L L I N G T O N-J O N ES}

In 1911, an eminent amateur prehistorian pulled the broken end of a pointed wooden shaft from Palaeolithicage sediments at a seaside town in Essex. This artefact, still the earliest worked wood to be discovered in the world, became known as the Clacton spear. Over the past one hundred years it has variously been interpreted as a projectile weapon, a stave, a digging stick, a snow probe, a lance, a game stake and a prod to ward off rival scavengers. These perspectives have followed academic fashions and as the popular views of early hominins have altered. Since discovery, the Clacton spear has also been replicated twice, has undergone physical transformations due to preservation treatments, and has featured in two public exhibitions. Within this article the changing context of the spear, its parallels, and all previous conservation treatments and their impacts are assessed.

\section{INTRODUCTION}

At 400,000 years old, the yew-wood Clacton spear is the earliest known worked wooden implement and has appeared in academic articles ever since its discovery in I9I I by Samuel Hazzledine Warren. When it was excavated from waterlogged sediment the spear possessed high water content but has since been treated with glycerol, alum and paraffin wax, and allowed to dry out. Comparison with early casts and documentation shows that shrinkage and warping have occurred.

When it was discovered in a foreshore exposure of Pleistocene sediments near Clacton-on-Sea, Essex, the tip of a wooden spear, encrusted with calcium carbonate, was mistaken for an antler tine. These Clacton channel deposits consist of fluviatile gravels and sands (also containing a stone tool assemblage) overlain by increasingly estuarine marls. Warren $(1922,597)$ interpreted the deposits as a tributary of the Thames but it was later recognized as part of the main Thames-Medway channel (Oakley and Leakey 1937). The environment of deposition has been interpreted as lush mixed oak forest and, to a lesser extent, open grasslands, bordering a river valley. During the deposition of successive beds the forest became more coniferous (Oakley et al. I977, I4), especially dominated by Abies sp. (firs). Fauna included Trogontherium sp. (giant beaver), Microtus agrestis (field vole), Equus mosbachensis (extinct horse), Stephanorhinus hemitoechus and S. kirchbergensis (extinct open and woodland habitat rhinoceroses), Sus scrofa (wild boar), Dama clactoniana (extinct deer similar to fallow deer), Cervus elaphus (red deer), Megaloceros sp. (extinct giant deer), Bos primigenius (aurochs), Bison priscus 
(steppe bison), Palaeoloxodon antiquus (straight-tusked elephant) and Mammuthus trogontherii (steppe mammoth). For a full discussion of the Clacton deposits and their wider relationships, see Bridgland et al. (I999).

The wooden implement was tentatively ascribed as a spear-point by Samuel Hazzledine Warren when he presented it to the Geological Society of London (Anon. I9II, xcix). Warren created a plaster cast and donated it to the British Museum and in 1922 he became more certain of it being part of a spear (I922, 597). In 1949 it was sampled and identified as yew. Warren stored the spear in glycerine until I952 when he donated it to the British Museum (Natural History) now the Natural History Museum, London, UK, and it was later sent for hardening at the museum's laboratory, but the tip became distorted during treatment. In 1958 the Clacton spear featured in an exhibit in the central hall of the British Museum (Natural History) called 'A Phase of Life in Palaeolithic Britain'. It was sampled again in I977 when three sections were taken at the Royal Botanic Gardens, Kew, and in 2007 researchers at the Natural History Museum (NHM) brought the Clacton spear to the Conservation Centre with the request that its deformation be rectified. The option of 're-shaping' was rejected after investigation, ethical consideration, and discussions with researchers and the curator. Past conservation treatments did, however, allow the artefact to be moulded safely, and an accurate cast made. The adhesive of one of the sampled sections failed in 20I3 and the spear-tip was repaired, and a year later it featured as one of the star artefacts in the 'Britain: One Million Years of the Human Story' exhibition at the NHM.

This article docun the last Ioo years of the Clacton spear's story, via the context of developments in lower Palaeolithic research, the spear's significance and its parallels (the Lehringen and Schöningen spears), the preservation treatments of I952, the ethical considerations surrounding restoration and the most recent techniques of replication.

\section{THE CLACTONIAN INDUSTRY WITHIN THE CHANGING CONTEXT OF LOWER PALAEOLITHIC RESEARCH}

Samuel Hazzledine Warren began collecting artefacts along the Clacton foreshore around I908. As his collections grew, it became apparent that the Clacton material differed from the familiar handaxe-rich Acheulean industries of the river drifts of Britain and France. The Clacton localities lacked any evidence of handaxes at all, being characterized instead by 'simpler' tools, such as flakes, scrapers, denticulates, notches, cores and choppers. When similar assemblages were identified elsewhere, most notably in the Lower Gravels at Swancombe, it became apparent that Clacton was not an isolated occurrence. Warren's early attempts at explaining the phenomenon suggested there were two contemporary hominin 'races', each producing distinct material cultures (Warren I922). To differentiate it from known industries it was named the Mesvinian, and subsequently changed to Clactonian.

Later interpretations took a wider perspective, encouraging long-range correlations of archaeological horizons. Separate tool groups were still considered to represent separate cultures, whilst any intermediate assemblages were interpreted as cultural 
intermixing or borrowing of ideas. Oakley and Leakey (1937, 217) proposed that the Clactonian industry was a widespread cultural tradition of Asiatic origin. They also believed that sites could be relatively dated based on an 'evolution' in tools: Clactonon-Sea was a mid-point in the lineage, ancestral to the Mousterian industries, contemporaneous, as different 'racial' groups, to the Acheulean industry. By the I940s concerns grew regarding whether the Clactonian represented development within one culture, or more than one culture developing in parallel, but after the Second World War ideas of cultural progression and the superiority of different 'races' became understandably unfavourable.

Since the I970s such cultural interpretation has fallen out of favour, and more dynamic understandings of stone-tool variation have emerged. For example, Ohel (1979) proposed that Clactonian sites were preparatory areas for the initial processing of raw materials by Acheulean knappers, while McNabb (2007) offered a combination of similar activity-related explanations, and the possible effects of raw material availability and selection on tool manufacture. Mithen (1994), following Collins (1969), suggested that the Clactonian sites were formed in more forested environments than the open Acheulean sites, which generated lower social interaction and regularity in behaviour, but $\mathrm{McNabb}$ and Ashton (1995) disagreed, since many Acheulean sites were also in forested areas. The suggestion that Clactonian tools were specifically for wood-working was discredited by the discovery, in 2003, of the Ebbsfleet assemblage, which was used for butchery (Stringer 2006, I25; WenbanSmith 2013), whilst Ashton et al. (2005, 56) believe that the distinction between Clactonian and biface industries could be a taphonomic phenomenon and that a cultural grouping cannot be based on the absence of evidence. At present there is no consensus on the meaning of the Clactonian, but most authorities recognize that there is an enigma to be explained.

The advances of the past three decades lay within establishing a more complex view of climatic fluctuations through marine isotope sequencing (Stringer and Gamble I995, 42-44). Prior to the I980s, sites attributed to the Hoxnian Interglacial were believed to be only 220,000 to 250,000 years old, and evidence of the oldest occupation of Britain. By the end of the decade, thanks to a more multidisciplinary approach, these sites were proved to be much older, although still younger than Boxgrove in Sussex and High Lodge in Suffolk (approximately 500,000 years old), both of which contained very technologically advanced tools (McNabb 2007, 297; 300) highlighting that an attempt to categorize a lithic assemblage to a particular time period is difficult. The Clacton and Swanscombe Hoxnian Interglacial sites are now considered well-dated to MIS (Marine Oxygen Isotope Stage) I I (424 to $374 \mathrm{ka}$ ) (Bridgland et al. I999, I4I-I42). In Britain, the hominin at Boxgrove is considered to represent Homo heidelbergensis and the Swanscombe individual to represent an early H. neanderthalensis (Stringer 2006; 20II). Stringer (2006, I28) believes that a Clactonian human has yet to be found in Britain, and its species remains unclear.

For many years these early hominins were considered to lack complex planning and social organization, and relied on scavenging for acquiring food: the Clacton spear was viewed as a snow probe for finding frozen carcasses. The discovery of a circular hole in a horse scapula excavated at Boxgrove changed these viewpoints, since it was considered 
to have been created by a spear-point and is Ioo ka older than the Clacton implement (Pitts and Roberts I997, 26I). Now it is widely accepted that the inhabitants of Boxgrove were effective hunters (Stringer 2006, 9; Smith 2012, 373).

THE SPEAR'S SIGNIFICANCE AND PARALLELS
Wooden artefacts of Palaeolithic Clacton spear was an isolated oddity. The Clacton implement itself was accepted as a tip of a wooden spear until the early I970s, at which point it was considered to possess an unusually robust shaft for a spear (Oakley et al. I977, I5). Suggestions of its purpose included a digging stick, game stake (hidden in a trap), a snow probe, and a weapon for warding off other scavengers. This mirrored perceptions that early hominins were scavengers and not hunters. Oakley et al. (I977, I7) revisited the question of the Clacton spear's use and concluded that the parallel striae on the spear were preshrinkage and pre-depositional, and were in fact tool marks created by fresh flint. This proved that it was indeed worked by hominins, but the authors believed there was no way of knowing which type of tool was used. They did believe, however, that the effort expended in sharpening the implement, removing bark and smoothing the nodes, did not seem consistent for its use as a digging stick. The profile of the tip and the lack of distinctive wear and gloss that digging would create also rule out this use (Oakley et al. 1977, 22). The break in the spear would have required considerable force so Oakley et al. (I977, I9) then considered whether it could have been a used as a stake in a game trap. The shaft thickness, although greater than many known throwing spears in ethnographic contexts, was considered insufficient for a game stake. A thrusting or throwing spear was concluded as the most viable use, any further distinction being deemed unattainable since the rest of the spear has not been preserved (Oakley et al. I977, 22). McNabb $(2007,345)$ promotes the idea of plasticity of tool use amongst the Lower Palaeolithic stone tools, and there is no reason not to assume that the spear also served multiple uses.

McNabb's experiments revealed that the most efficient tool, from the available assemblage, for creating the Clacton spear's profile is the Clactonian notch (McNabb I989, 25I). This type of flake possesses a concave removal that forms a curved cutting edge. The notch would have been used for more than one technique: firstly for planing the form and then a rapid inward scraping motion to create the finish (McNabb I989, 252; 253). It has been found that crafting a spear from yew (a particularly hard wood) takes $23 / 4$ hours (McNabb I989, 253). It is therefore a far greater time investment than the creation of a stone tool, and also requires the initial manufacture of the notched flake. The choice of yew, which will take more time but achieve better results than a softer wood, displays accumulated knowledge and raw material selection.

The Schöningen spears, discovered in Germany in 1995 and subsequent years, received far more acclaim than the Clacton spear (Dennel I997); they were hailed as the oldest known spears and showed 'design and construction skills previously attributed only Qpodern humans' (Kouwenhoven 1997), ignoring the existence of the Clacton spear! Amhough initially believed to be $400 \mathrm{ka}$ old (Thieme I997, 807) the Schöningen 
spears are now thought to be about $295 \mathrm{ka}$ old (the end of MIS 9), post-dating the Clacton spear by more than I00,000 years (Barham 2013, 234-5). The Schöningen spears were discovered in association with stone tools and horse bones with butchery marks and have been accepted as proof that early hominins hunted and had foresight (Thieme I997, 807; Thieme I999, 394). The initial interpretation of large-scale slaughter by a large social group, hundreds strong, has been disproved by dating the associated faunal remains, and it is now believed that the social groups were more likely to number twenty to thirty (Balter 20I4, I082). The spears are, at least, the oldest complete wooden weapons yet discovered, although whether they were throwing spears (as their javelin-like balance could imply) or thrusting spears, is still unclear. In trials, Thieme (2005, I28) records a $60 \mathrm{~m}$ range with good penetration power; other researchers place this at a considerably lower I $5 \mathrm{~m}$ (Churchill and Rhodes 2009, 202) whilst Villa and Lenoir $(2009,79)$ report the range of Roman throwing spears as $30 \mathrm{~m}$, with only is $\mathrm{m}$ for a kill. Shea (2009, I 89) notes that the dimensions of the tips of the Schöningen spears are much greater than ethnographic examples of throwing spears and believes that, if they were indeed designed for throwing, their effective range would be correspondingly lower. Churchill (1993, 26; 29) surveyed 96 ethnographic and ethnohistoric groups and discovered that thrusting spears and throwing spears are both shortrange techniques (hand-thrown spears averaging a $6 \mathrm{~m}$ range); he also concluded that thrusting and throwing spears are often interchangeable and are mainly used for the same two hunting styles: disadvantage (driving game into a trapped position, e.g. up against a water body like the Thames-Medway channel) and ambush. Both disadvantage and ambush styles utilize the natural habitat and are highly co-operative. Churchill also concluded that spears are predominantly used on large prey: a huge animal can be killed, as long as it remains still enough to allow the delivery of several thrusts. This is the method that modern humans have used to hunt elephants, hippos and walrus. If the Clacton spear is a thrusting spear then it could we $\rightarrow$ ply highly co-operative hunting amongst early hominins. A hunting technique in th ameroon has been documented, however, that involves a single strike from a thrusting spear into an elephant, which is subsequently trailed until it dies of its injury (Pitts and Roberts I997, 262). This is not a widespread technique however, and, although it demonstrates that spear hunting is not necessarily a co-operative behaviour, the processing of a large carcass, and its defence against scavengers, is nevertheless likely to require a certain level of co-operation.

The Schöningen spears were interpreted as javelins due to their balance and shape (Thieme 1997). Stringer (2006, I73) believes, however, that the physical build and injuries suffered by Neanderthals correspond to a confrontational hunting style: thrusting or short throwing of spears at close proximity to prey. Furthermore Neanderthal remains lack a displacement of one shoulder joint (bilateral asymmetry in humeral retroversion), implying that they did not throw projectiles (Rhodes and Churchill 2009; Schmitt et al. 2003). Habitual frontal throwing creates distinctive changes to human diaphyseal geometry, which only appears after $20 \mathrm{ka}$ (Rhodes and Churchill 2009). This is supported by other osteological indicators such as the deltoid muscle attachment and scapular glenoid fossa (Churchill and Rhodes 2009, 20I), whilst the shorter forearms and ulnar trochlear notches of Neanderthals would reduce the ability to accelerate projectiles for long distance throws (Churchill and Rhodes 2009, 
204). Shaw et al. (2012) propose that Neanderthal arm morphology supports scraping activities as opposed to spear-thrusting, although this is not widely accepted. Regardless, the physical evidence for Neanderthals and other early hominins implies that not only did they not throw habitually, they could not have thrown far.

The Lehringen spear (found near 1 en, Germany in 1948), is also of yew wood. It has been dated to MIS se (I ta), much more recent than the Clacton spear, but still long before Homo sapiens reached Europe (Pitts and Roberts I997, 26I; Roebroeks 2008, 925). Oakley et al. (I977, 23) deemed the Lehringen implement as a thrusting spear, based on its weight distribution (heavier at its proximal end). It is believed that charring, to speed the sharpening process, was used in its creation (Movins I950; Jordan I999, 90), which is a common practice within the ethnographic record (Waguespack et al. 2009, 788). If fire was also used to harden the Clacton spear-tip, this would be very significant: fire enabled cooking, improving health, indirectly allowing smaller jaws and teeth to evolve, and may even have contributed to social evolution (Stringer 2006, I28). In addition, the lack of hearths within Clactonian sites (Stringer and Gamble I995, I56) would make the spear a significant contribution to the limited evidence that Lower Palaeolithic hominins did indeed possess fire. However, Oakley et al. (I977, I7; 28) believed that the penetration layer on the x-ray (Illus. 3) proves that the Clacton spear could not have been shaped using fire because the charring would have sealed the cut ends of the tracheids (longitudinal wood cells). A replica of the Clacton spear was created for the 'Britain: One Million Years' exhibition at the NHM in 2014 and exhibited next to the spear itself. This was created using charring and scraping. The tip was subsequently shaped, removing the charred and, presumably, sealed outer layer. It is possible that the heat-affected outer layer of the real spear was also removed, again exposing open tracheids. The question of whether or not the Clacton spear was created with the use of fire became less significant with the discoveries of several hearths at Schöningen. The veracity of these Schöningen 'hearths' has since, however, been questioned (Barham 2013, 235; Balter 20I4, I083) so perhaps the evidence from the spear is again important.

Organic implements require significant consideration, but very few have yet been discovered. Retouched flakes have been found to have little use for working wood (McNabb I989, 255) and the lack of retouching in an assemblage may therefore imply a wood-working industry. This supports microwear analyses that revealed that many of the Clactonian tools had been used on wood (Oakley et al. I977, I8). Waguespack et al. (2009, 788) found that wood-only hunting weapons are abundant within the ethnographic record, and propose that the lack of Palaeolithic examples stems from preservational rather than technological reasons. Warren $(1922,598)$ and later Tyldesley and Bahn (1983, 59), were correct: wood may have been as significant an industry as flint, stone tools were in many cases just a step in the creation of wooden implements, and the technology was far in advance of what we currently imagine. Perhaps within wooden implements lies the contradiction to the perceived 'technological and behavioural monotony of the Lower Palaeolithic' (Scott 20I I, 2). 


\section{TREATMENT HISTORY}

When first discovered the spear 'had calcareous encrustations on its surface' (Anon. I9I I, xcix). It is not known how or when these were removed but it is known that in I95I Mr Warren donated a sample of wood from the spear (E I520) to the Natural History Museum and it was registered as Taxus baccata.

The spear was stored in glycerine for forty-one years until it was treated at the Research Laboratory of the British Museum in March 1952 by Dr A. E. Werner (Oakley et al. I977). Unfortunately the British Museum has no record of this, and Werner did not join the institution until I954. It must be assumed that Werner completed this treatment privately or that sources (Oakley et al. I977) were mistaken.

A transcription of Dr Werner's treatment follows:

'The waterlogged specimen was immersed at a temperature of $93^{\circ} \mathrm{C}$ in a saturated solution of alum, to which a little glycerine was added, and it remained immersed in this solution for about 3 hours. After removal it was allowed to cool and any excess of alum that had crystallized on the surface was washed off. At this stage, the tip which had broken off before arrival at the Laboratory was reattached with Durofix. Finally, the specimen was further consolidated by immersing it in a bath of paraffin wax at $70^{\circ} \mathrm{C}$. The results of this treatment were regarded as satisfactory. It is not known at what stage in the proceedings shrinkage and warping took place' (Oakley et al. I977, I4-I 5 ).

Werner does not state the reasoning behind these treatments.

In 1976 another four sections were taken and the genus was confirmed as yew (Taxus sp.) at the Royal Botanic Gardens, Kew. An old image has been discovered at the Natural History Museum, clearly showing a transverse cut or break towards the tip (Illus. I). This may be the site of the sectioning mentioned previously. In 2007 this was visually undetectable, implying that unrecorded conservation treatment has been carried out to make this defect invisible.

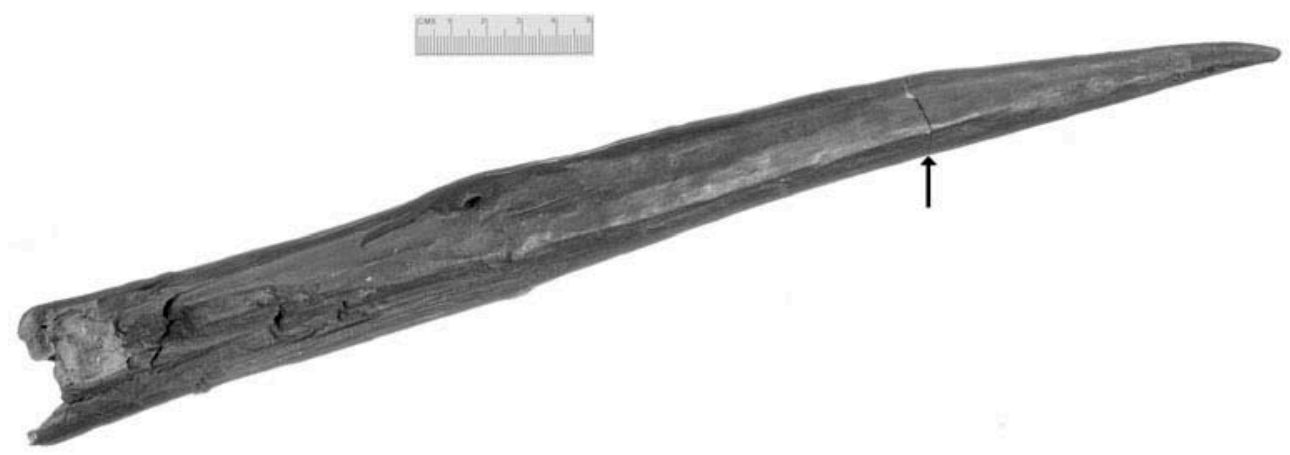

ILLUS. I Reproduction of a black-and-white image discovered at the Natural History Museum. Unfortunately the date of this image is unknown, due to destruction of many photographic records by fire in I969. The transverse cut or break-line is indicated by a black arrow 


\section{DISCUSSION AND CONTEXT OF PREVIOUS TREATMENTS}

Articles published within seven years following the treatment of the spear by Werner, describe freeze-drying and sublimation (in water, carbon dioxide, liquid oxygen and trimethyl carbinol) and also heated polyethylene glycol 4000 treatments (Organ I959; Rosenqvist I959a). Organ does not state the degree of shrinkage observed in these experiments but describes the latter as giving the 'most satisfactory' results. A proliferation of experimental techniques and materials for waterlogged wood were developed in the I960s to early I980s. These included consolidation with polyvinyl acetate (Mühlethaler 1973), methyl cellulose (Munnikendam I967), sucrose (Kazanskaya and Nikitina 1984) or dammar resin in ether (Blackshaw 1974) and also epoxy, polyester, melamine-formaldehyde (Arigal-C), urea-formaldehyde and phenol-formaldehyde prepolymers in solution, followed by the appropriate catalyst (Müller-Beck and Haas I960; Schaffer I97I). This increased interest was possibly initiated by the drainage of the Zuiderzee (north-west of the Netherlands) and discovery of an unprecedented number of shipwrecks and waterlogged artefacts. From this time period emerged two preferred methods: one or two-stage treatment utilizing different molecular weight polyethylene glycols (Albright I966; Stark I976; Hoffman I986; Jover I994) +/- freeze-drying (Schnell and Jensen 2007), and the in situ polymerization of monomers by gamma radiation (Munnikendam I967; Šimůnková et al. I983). More recently silicone-based polymers have been considered for conservation of waterlogged wood (Kavvouras et al. 2009) although these materials have been found to be ineffectual by other conservation specialists (Favaro et al. 2005).

The spear was treated in 1952 , before these techniques had been devised.

Glycerine (glycerin; glycerol; propane-I,2,3-triol, $\mathrm{C}_{3} \mathrm{H}_{5}(\mathrm{OH})_{3}$ ) was probably chosen by Warren, and subsequently Werner, because it is a humectant (promotes water retention) and is a contact bacterial dessicant, essential when artefacts are excavated to aerobic conditions (de Jong I979).

Alum (hydrated potassium aluminium sulfate, $\left.\mathrm{KAl}\left(\mathrm{SO}_{4}\right)_{2} \cdot \mathrm{I}_{2} \mathrm{H}_{2} \mathrm{O}\right)$ is a water-soluble, acidic solid with antibacterial properties. The use of pure boiled alum (as an alternative to schnapps) followed by a linseed oil or mastic varnish was invented in I859 at the Museum of Nordic Antiquities in Denmark (Madsen et al. 200I). Rosenqvist (I959b) describes the 'alum method (without glycerol)' as immersion in alum at $\mathrm{IOO}^{\circ} \mathrm{C}$. Alum was chosen because its solubility in water increases with increasing temperature and will re-crystallize upon cooling. The alum method became the standard treatment for waterlogged wood at the National Museum of Denmark (formerly the Museum of Nordic Antiquities), from I 859 until a glycerine-alum-linseed oil technique was developed in I962 (Christensen I97I). Plans to treat the first Ferriby boat (excavated in I940) with glycerine-alum were abandoned because the smell was too bad, although the treatment had proved successful on several small objects (Baker I975). After immersion in heated glycerol and alum, the cooled object was coated in warmed linseed oil and then a thin coat of shellac. This aimed to prevent absorption of water from damp surroundings (Padfield I992). Linseed oil is commonly used to treat furniture, it shrinks little on hardening and does not expand pores when it soaks in, but it has a high 
unsaturated ester content, yellows with age (Snethlage and Wendler 200o) and has been found to continue to oxidize after curing (Rosenqvist I959b).

Rosenqvist (I959b) reported that five years after treatment with pure alum, linseed oil and lacquer that the alum was still stable and the artefacts had not shrunk further, but some of the wooden objects had broken due to their low mechanical strength and, presumably, poor handling. It has subsequently been found that waterlogged wooden artefacts treated with alum suffer from salt precipitation, surface flaking, internal cracks, and pulverization after IOO years (Braovac 200I). It is not known if Werner replaced the alum with paraffin wax or simply used the wax as a coating. The spear will therefore have to be monitored for signs of deterioration.

Paraffin wax (an alkane hydrocarbon, $\mathrm{C}_{20} \mathrm{H}_{42}$ to $\mathrm{C}_{40} \mathrm{H}_{82}$ ) is very unreactive as it is non-polar and lacks functional groups. It will only oxidize to fatty acids at high temperatures, in a molten state, with oxygen bubbled through it (Perchenko and Serov I980) and will not cross-link without the addition of Dicumyl peroxide (Mhlongo et al. 200I). Paraffin wax possesses greater transparency than microcrystalline wax (Masschelein-Kleiner I985) so potentially has a lesser effect on the appearance of artefacts. Paraffin wax is also a common embedding medium for preparing histological tissue samples for light microscopy. Interestingly, potassium aluminium sulphate is used prior to this treatment as a mordant for stains (Crowley 20I0). Nakhla (I986) states that natural resin and paraffin wax mixtures had been used in preceding years with unsatisfactory results, but does not explain why both substances were used or substantiate this information. Paraffin wax has, however, commonly been used to consolidate other organic materials (Boettcher I9I2; Lucas I943; Paulke 2003; Rice I966) and an unspecified wax was experimentally used to preserve waterlogged wood in Denmark in I859 (Madsen et al. 200I).

Werner (I96I) describes an 'alum process' for conservation of other wooden artefacts, but does not mention glycerol or paraffin wax. Werner may have added paraffin wax to the spear as a water/oxygen barrier, as recommended by Organ (I963) several years later, or to increase mechanical strength. Seven years after Werner's treatment, Rosenqvist (I959b) mentions the work of a colleague who leached the salt from alumtreated wood with water and replaced it with paraffin wax. This replacement appears to be an afterthought; it is not clear why Werner would have chosen to carry out the processes in rapid succession. Rosenqvist (I959b) believed the risk of such treatments to be too great.

Durofix, used for the repair in 1952 , is a cellulose nitrate adhesive with plasticizers dibutyl phthalate, camphor, or triphenyl phosphate (Horie I987). It is compatible with most synthetic and natural resins (Shashoua et al. I992) but is now not generally recommended because it tends to yellow and deteriorate: migration or volatilization of plasticizers results in severe shrinkage, potentially damaging objects (Shashoua et al. I992). Furthermore, some cellulose nitrate adhesives degrade spontaneously to produce nitrogen oxides which, in the presence of moisture, form corrosive nitric acid (Hoadley 1978). No damage has been observed to the repair on the spear, but it should continue to be stored at $45 \pm 5 \%$ relative humidity, $20 \pm \mathrm{I}^{\circ} \mathrm{C}$ and zero light (Hoadley I978; Selwitz I988). The Durofix adhesive remained stable until 20I3 when it failed; the exact cause is unknown, but low mechanical strength is likely. 


\section{EVALUATION OF THE TREATMENT}

Observers in I9I I and I932 stated that the spear was straight and tapered to a fine point (Anon I9II; Oakley et al. I977), whilst in an early photograph of the spear (Crawford I92I, facing page I6) the tip is not any finer than its current state, but it does appear less warped. Unfortunately the photograph was taken of the angle shown by the third outline from the left in Illus. 2, which is the least deformed. In his account of the I952 treatment Werner wrote 'It is not known at what stage in the proceedings shrinkage and warping took place' (Oakley et al. I977, I5). As water held in the capillaries of wood evaporates, surface tension forces increase and weak cells will collapse (Kaye et al. 2000). The shrinkage and warping of the spear could be due to the high temperature used in Werner's treatment, insufficient strengthening and swelling of cells or due to problems with the treatment materials themselves. Shrinkage can occur if macromolecules of the impregnating resin do not diffuse rapidly enough due to

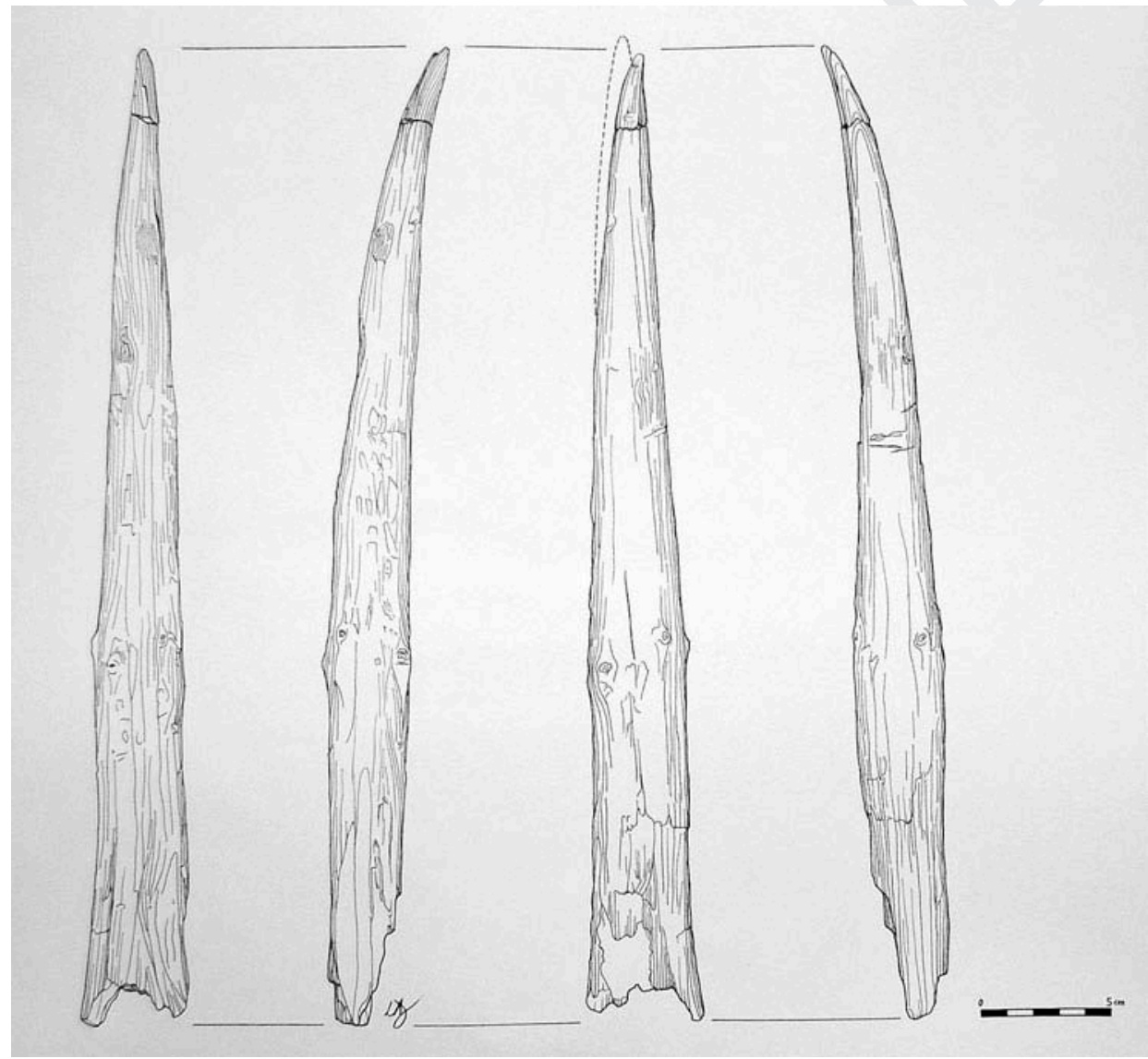

ILLUS. 2 Line drawing (by author) showing views of the Clacton spear and an outline of the original shape, derived from the old casts 
a large difference in diffusion coefficient with water (Munnikendam I973). Shrinkage of the spear may therefore have occurred because the paraffin wax molecule was too large to penetrate the cell wall of the wood (Mühlethaler I973) or there was not enough time for diffusion to complete, or because the wax was only applied as a coating. It is not known which molecular weight paraffin wax was used by Werner. Paraffin wax shrinks as it cools and crystalizes (Freund et al. 1982) which could also have caused the warping, whilst alum is an astringent agent which could also have caused constriction and shrinkage of the spear. Uneven shrinkage will occur if deterioration is uneven, for example in more permeable or accessible areas (de Jong 1979) whilst heartwood and sapwood will degrade differentially and therefore shrink to different degrees (Mühlethaler I973). In addition, pressure of burial can cause thin-walled early wood cells to collapse (Hoffman and Blanchette I997); this could explain the warping of the spear during treatment, in the direction of an existing bend. In a description of a photograph from I92 I the spear is claimed to be 'nearly straight, although the tip is slightly bent in the direction of subsequent warping' (Oakley et al. I977, I3).

X-rays of the Clacton spear were taken at the NHM in the I970s (Illus. 3). The outer area of increased opacity on the X-ray image has been interpreted as penetration of a substance along artificially cut tracheids (Oakley et al. I977). The double 'flame' shapes (one in the broken tip and one in the shaft behind it) do imply this to be the case, and also that impregnation occurred before the tip was re-adhered. It is not known whether this boundary represents the penetration depth of the alum or of the paraffin wax, but complete impregnation clearly did not occur. The x-ray was presumably taken before Illus. I, since the transverse cut is not apparent.

Werner believed the 1952 treatment to have been satisfactory. To assess this claim, the amount of shrinkage, during and after treatment, should be compared with other treatments. The current and past dimensions of the spear are shown in Table I. Warping accounts for $5 \mathrm{~mm}$ of the $20 \mathrm{~mm}$ reduction in length. Pure shrinkage caused a $3 \mathrm{~mm}$ reduction in diameter. This translates to a $3.8 \%$ radial shrinkage and $3.9 \%$ tangential shrinkage. Rosenqvist (1959a) states that untreated waterlogged wood will suffer $6 \%$ radial shrinkage and $80 \%$ tangential shrinkage upon drying. Munnikendam (I973) achieved 4.9\% tangential shrinkage following treatment with Glycol methacrylate. Stark (I976) reports I3 \% radial shrinkage and $8 \%$ tangential shrinkage after Polyethylene glycol impregnation, although Mühlethaler (I973) achieved a much more successful amount (0.7 \% radial shrinkage) with a similar method. Compared with these reports, Werner's treatment was reasonably successful.

The spear is described thus in I977:

'a portion of a branch of a yew tree, one end of which tapers to a point and the other is unevenly broken. It is $367 \mathrm{~mm}$ long and has a maximum diameter in the region of the whorl of knots of $36 \mathrm{~mm}$. The terminal $32 \mathrm{~mm}$ section of the tip has been broken and reattached without loss of material, but there is also a longitudinal split running $82 \mathrm{~mm}$ down from the tip. The broken end of the specimen is badly damaged: on one side the wood is badly fractured, and on the other a long splinter of wood has been split away well over half the length of the fragment; in addition, the broken end is badly split and the end is splayed out, but the damage has been restricted by the whorl of knots which has stopped the splitting from passing up into the tip.' (Oakley et al. I977, I3).

\section{5}




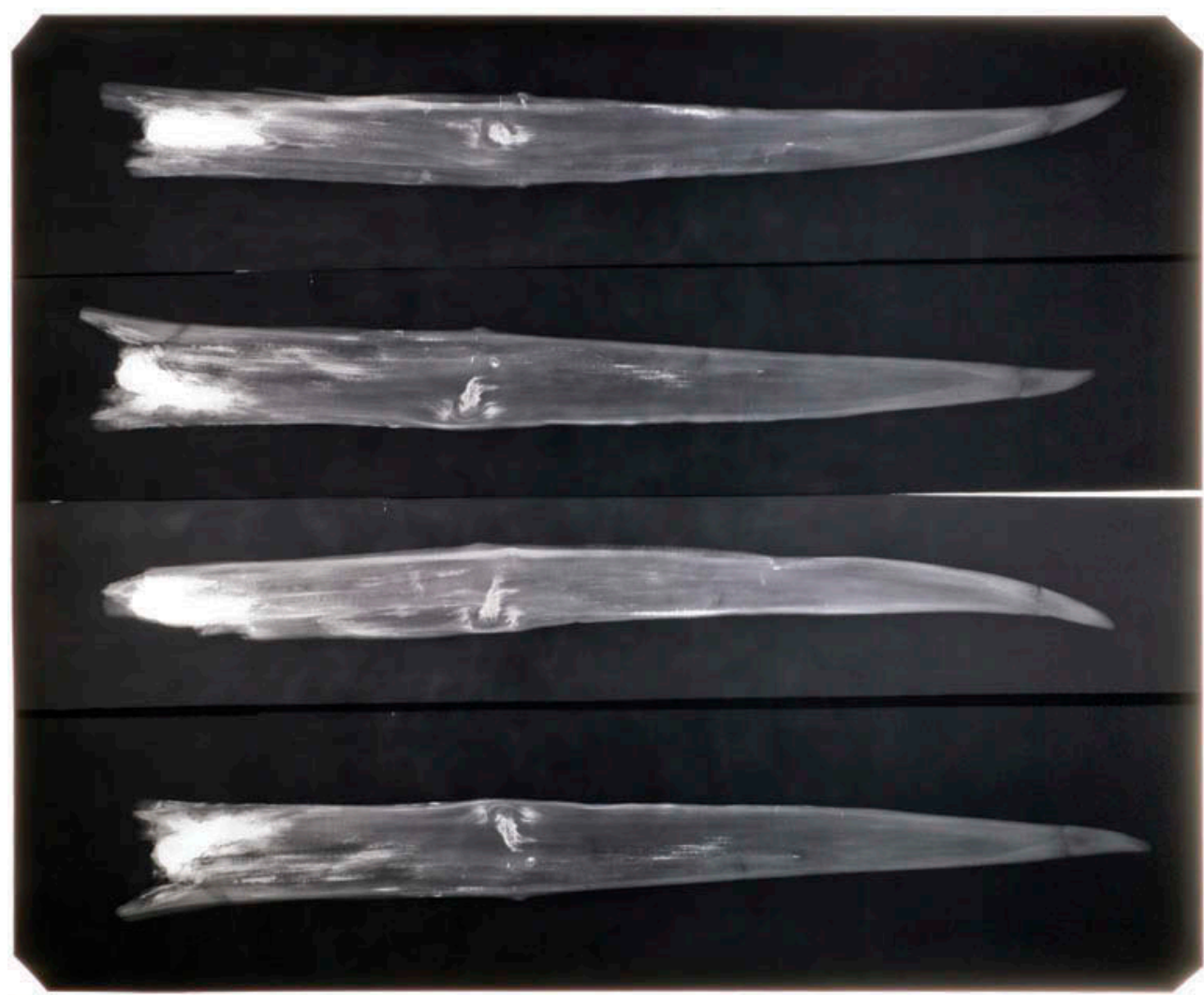

ILLUS. 3 X-radiographs of the Clacton spear (unknown photographer, digitized by Image Resources department at the NHM)

TABle I Record of Distortion. Measurements prior to 2007 derive from Oakley et al. (I977) except for the I9I I diameter, which was taken from the I9I I cast

\begin{tabular}{lcc}
\hline YeAr & Length $($ MM) & Diameter (MM) \\
\hline I9II & 387 & 39 \\
I932 & Not warped & \\
I974 & 367 & 36 \\
I977 & 367 & 36 \\
2007 & 367 & 36 \\
2012 & 367 & \\
\hline
\end{tabular}

The spear does not appear to have deteriorated any further since this account was written. Neither does the spear seem to have shrunk or warped significantly since wax impregnation in I952 (Oakley et al. I977) and now appears stable. 


\section{REVIEW OF TREATMENT REVERSIBILITY - PRACTICAL CONSIDERATIONS}

Alum is water soluble whilst paraffin wax is insoluble in water but soluble in ether, benzene, certain esters, and trichloroethylene (Nakhla I986). These treatments are therefore (theoretically) reversible, but in practical situations waxes have proved far harder to remove than theory suggests (Moffett I996). For joints where wax has been used as an adhesive, a poultice of surgical cellulose soaked in Methylene chloride has been suggested, but this is accompanied by warnings that it is near impossible to remove from porous surfaces, such as wood (Rixon 1976).

The spear has not only undergone shrinkage and warping, but also embrittlement during burial through loss of cellulose. The paraffin wax has stabilized the artefact and its removal could cause cell collapse to continue and leave the artefact extremely fragile and at risk from physical damage. Disintegration could also occur as the cells swell. Rehydration of wood is extremely risky and generally ineffective (Dewolf 2007; Hamilton 2007; Bamforth 2007, pers. comm.): for example chemicals such as $\mathrm{I} \%$ sodium hydroxide (Jensen pers. comm.) peracetic acid $\left(\mathrm{C}_{2} \mathrm{H}_{4} \mathrm{O}_{3}\right)$ or chlorous acid $\left(\mathrm{HClO}_{2}\right)$ (Matsuda I985), which effectively swell the cells, also serve to deteriorate the wood itself. Thin sections have been rehydrated for the identification of wood species using these methods (Barbour I984; Matsuda I985) but peracetic and chlorous acids dissolve lignin and increase fragility, making wood treated in this way impossible to preserve in the same manner as naturally waterlogged wood. The rapid decompression of supercritical carbon dioxide fluid has been used with some success, but total recovery of initial shape was not achieved (Chaumat et al. I998). Many methods have been developed for the treatment of waterlogged wood (e.g.Grattan I982; Brunning et al. 20I4; Kennedy and Pennington 20I4; Walsh et al. 20I4) but these are unsuitable for the spear due to its treatment history.

A decision not to perform remedial interventions on the spear was made because the potential benefits did not outweigh the risks. Removal of the previous consolidants and re-hydration are extremely interventive methods which would increase the fragility of the artefact and create a high risk of further deterioration. The spear currently appears stable and it is more important to preserve the fine tool marks than to lose them in an attempt to straighten the tip. The curator and researchers agreed with this viewpoint as soon as they were made aware of the potential risks.

\section{REVIEW OF TREATMENT REVERSIBILITY - ETHICAL CONSIDERATIONS}

As well as the practical considerations already outlined, artefacts must be conserved within an ethical framework. The ethical principles of conservation are stakeholder consultation (accountability), discernible alteration, authenticity, a scientific approach, reversibility, minimal intervention, sustainability and equal standards. A conservator must consider all of these principles before undertaking any remedial intervention.

The aim to use only reversible treatments is an acknowledgement that previous considerations are no longer acceptable (van der Vall I999, I97), some materials have 
proved damaging (Hartin I990; Bomford I994) and current conservation methods may themselves prove to be flawed. Reversibility reduces risks and responsibilities (Muñoz Viñas 2005, I 85) but it was recognized as largely unobtainable in the I970s (Caple 2000, 64). Conservators now strive for retreatability, stability (Applebaum I987) and unrestricted future analysis (CAC-ACCR 2000, guidance I6). The premise of minimal intervention gained popularity when it was recognized that reversibility was unrealistic. It lies in considering all possibilities and choosing the option with lowest impact to achieve your goal, which can be extremely subjective. The concept of authenticity is even more complex: traditionally in conservation there has been only aesthetic, historical and physical authenticity. In the I980s conceptual integrity was added to incorporate cultural or religious significance (Clavir I998, 2). Authenticity can conflict with other values, such as the readability of an object, which in turn can be impaired by deterioration, and if the original materials have deteriorated, they are no longer in their original state and are therefore no longer authentic. Pearce (I990, I06) believes that only a version of an object can be preserved, not its 'true nature'. Caple $(2000,62)$ saw the true nature of an object as its original form, but 'relating the authenticity of an object to its original condition (or to any past or presumed condition) is an entirely subjective choice' (Muñoz Viñas 2005, I06). The only authentic state of an object is therefore its current condition and all attempts to recover an 'authentic' state are therefore preferences, not reality. Muñoz Viñas $(2009,36)$ maintains that conservation cannot make an object more, or even less, authentic. This would mean that any action would result in the objects new true state, nullifying the concept of authenticity. This should be recognized, but not be used as a licence to abandon the original premise, or as validation for every action.

Physical, aesthetic and historical integrity should be preserved where possible (Clavir I998), but to straighten the spear would destroy its historical integrity and place physical and aesthetic integrities at risk. Preserving original evidence, i.e. straightening the spear, is believed to preserve an object's conceptual integrity, but if deterioration and consolidation have occurred, then the original evidence has already been compromised. Professional opinions regarding restoration differ (Clavir 2002; ECCO 2008): to revert an object to its original form is to preserve the truth of the creator's intent but denies the truth of the nature of the materials and of the object's history. Clavir (2002) believes that conservation differs from restoration because the physical integrity of an object is being preserved as well as its aesthetics, and because it is based on scientific enquiry. To revert an object to its original form is to preserve the truth of the creator's intent but denies the truth of the nature of the materials and of the object's history. Invisible repairs would also be considered falsification by scientific conservation principles. Restoration can aid interpretation and conceptual accessibility (Pye and Sully 2007) but authenticity and legibility must not be confused with the imposition of preferred or expected states (Muñoz Viñas 2005). The straightening of the spear, for cosmetic purposes, would be an imposition of this kind and 'aesthetic surgery' belongs to the age preceding scientific conservation (Muñoz Viñas 2005).

The Clacton spear has acquired its own name and is famous amongst archaeological scholars, if not beyond. It has symbolic meaning, but as a spear and as a symbol of a spear it is quite unsuccessful. Although the spear has lost part of its significance (being 
bent, blunt and only the tip surviving) it still holds value as an ethno-historical piece of evidence. Preservation of the academic and scientific information it holds must take precedence over symbolic meaning. Oakley et al. (I977) proposed that the spear was broken during use (hunting), whilst the wood was relatively green. Some weapons discovered in lakes and rivers are believed to have been deliberately and ritually bent or broken (Oddy I994). If the Clacton spear was deliberately broken-off from the shaft, or damaged during use, the tip could also have been compressed or bent slightly at this time. In the earliest photograph (Crawford I92I) the tip does indeed appear slightly distorted in the direction of subsequent warping. To completely straighten the spear in this case would be unethical.

Some justification for restoration lies within the regain of an object's richest message, or if it will actively deteriorate if no action is taken (de Guichen 2007). Neither of these arguments hold true for the Clacton spear. To straighten the spear would destroy parts of its historical integrity and place physical and aesthetic integrities at risk. The original dimensions and shape of the spear are well documented, so other information, such as fine tool marks, must not be risked in an attempt at re-shaping.

\section{MOULDING AND CASTING}

Materially 'authentic' objects have more power than replicas, regardless of their quality (Muñoz Viñas 2005), but for scientific research a high-quality cast can possess almost equal value. The spear is required for research, which includes international loans. The risks from transportation and handling can be avoided if a cast is sent in its place.

A plaster of Paris cast was created in I9I I, which measured $383 \mathrm{~mm}$ compared with the $387 \mathrm{~mm}$ length of the spear at that time (Oakley et al. I977); this may have been due to contraction of the plaster during cooling and crystallization. Within the NHM two plaster casts are stored alongside the spear, presumably the same casts as mentioned above. These were presented to the museum in 1947 and registered as PA E I I 83. The casts are of low definition and cannot be used as a substitute for research purposes. They do, however, serve to indicate the spear's original dimensions (see dashed line on Illus. 2).

Although two transverse repairs were noted within the distal portion, it was considered that the spear was stable enough for a new mould to be taken because the paraffin wax has reduced the porosity of the wood, reducing the risk that moulding compounds could permeate the interstices. It was decided that a line drawing would be created (Illus. 2), a cast and master cast made, and the spear should be re-housed in conservation-grade materials.

The spear was lightly coated in a separating layer of $50 \%$ Teepol L in deionized water (Sodium alkyl sulphate with traces of formaldehyde, methanol and 2-bromo-2nitropropanol-I,3-diol with $\mathrm{pH}$ 7.5-9). Teepol $\mathrm{L}$ was chosen as a release agent due to its water solubility, anionic nature and neutral to slightly alkaline $\mathrm{pH}$. More traditional release agents such as an aqueous glycerine solution or a carbon tetrachloride and paraffin mixture (Rigby and Clark I965) were not used because they may have reacted with the chemicals added by Werner. A polyethylene glycol-based water-soluble putty was made up (Rixon I976) and applied into overhangs and cracks, to prevent the 


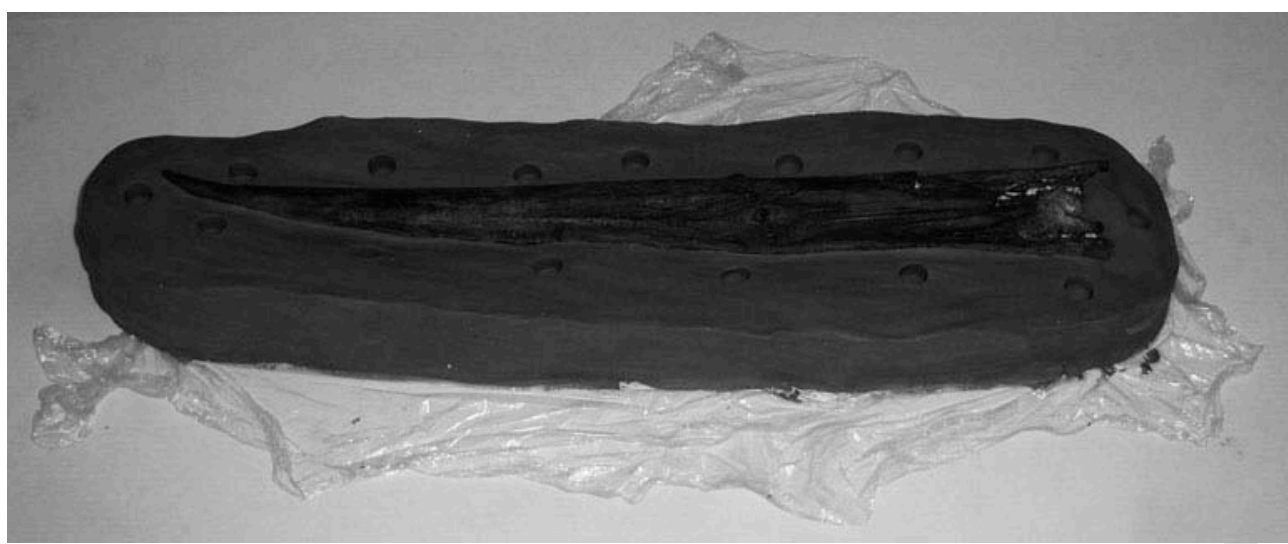

ILLUS. 4 Photograph of the spear during moulding. Note impressions within the modelling clay to create locking sockets, and white water soluble putty at the distal end. (Photograph by author)

moulding compound ripping the artefact apart when removed. Half of the spear was then protected by Clingfilm and embedded in a platform of modelling material (Newplast ${ }^{\mathrm{TM}}$ ) (Illus. 4). A thin layer of T20 silicone rubber (Alec Tiranti Ltd) was then painted over the top, to capture fine surface detail, and subsequent layers were built up with thickened silicone. Silicone rubber and epoxy resin will replicate features at resolutions of O.I-0.25 $\mu \mathrm{m}$ at magnifications of x2000 (Goodwin and Chaney I994). This was considered essential for replication of the fine tool-marks on the spear. A polyester resin and fibreglass jacket was formed over the silicone rubber, to prevent flexing during casting. The spear was turned over, the modelling material removed, and the exposed rubber coated with a Vaseline ${ }^{\circledR}$ separator (Goodwin and Chaney I994). The other half of the mould was then created with silicone rubber and a resin jacket and an epoxy resin master cast was made of each half of the mould, which included the silicone rubber surround (Illus. 5). Replacement moulds can be made from this in the future, without having to access the artefact again, significantly reducing the risk of future damage. The final cast was made by painting epoxy resin into the details of the mould cavity, followed by layers of epoxy resin thickened with slate filler. Acrylic paint was used to colour the cast to prevent interplay of light confusing external features, and to reduce the amount of over-painting required on the exterior. Once the two halves of the cast had been united and set, the excess resin at the join (flash-line) was removed with a scalpel. The whole cast was then over-painted with a thin wash of acrylic paint to match the original (Tiffany and Iwama I994) (Illus. 6 and 7). The Teepol L and putty were then carefully cleaned from the spear using deionized water and cotton swabs.

\section{RECENT DEVELOPMENTS}

In 2007 the spear's original label, written by Warren in I9I I, was discovered to have torn in half due to natural deterioration along a fold. It was relaxed for 30 minutes in an elevated humidity chamber at room temperature so that the edges could be unfolded 


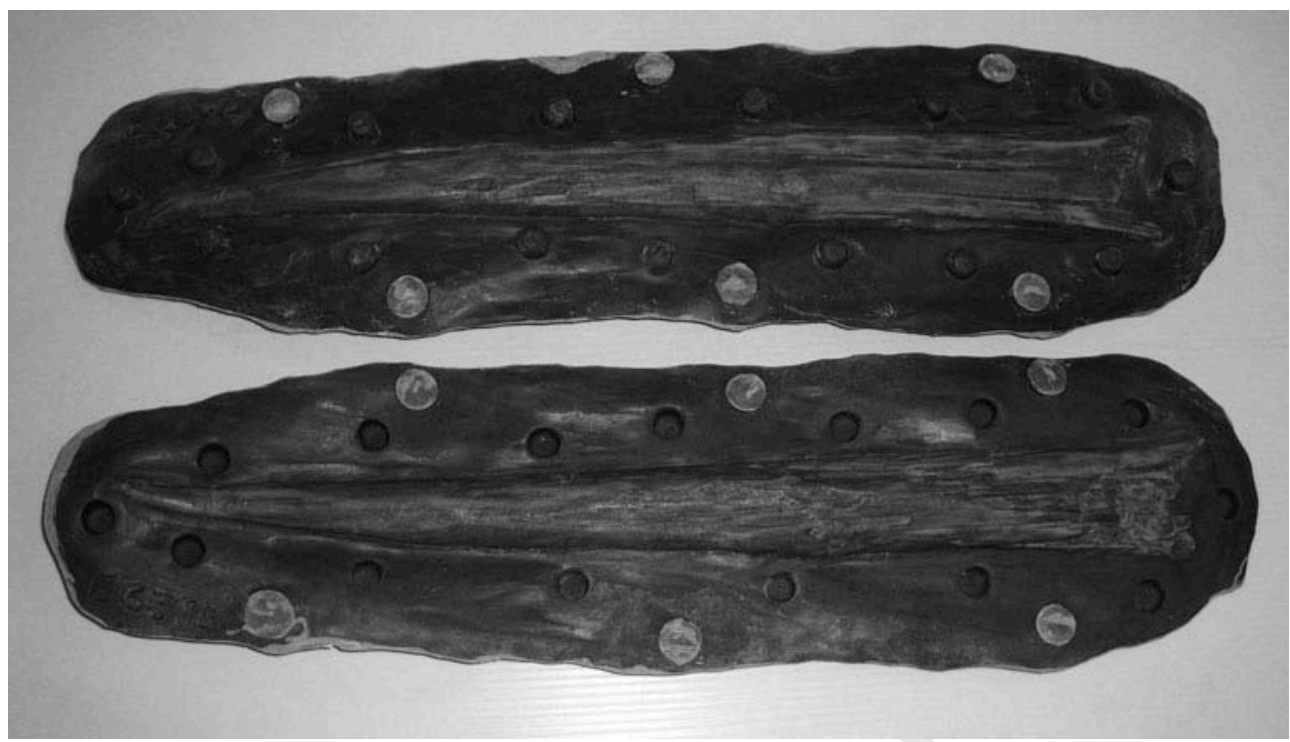

ILLUS. 5 The two-part master cast of the mould, from which subsequent moulds can be taken without exposing the object to further risk. (Photograph by author)

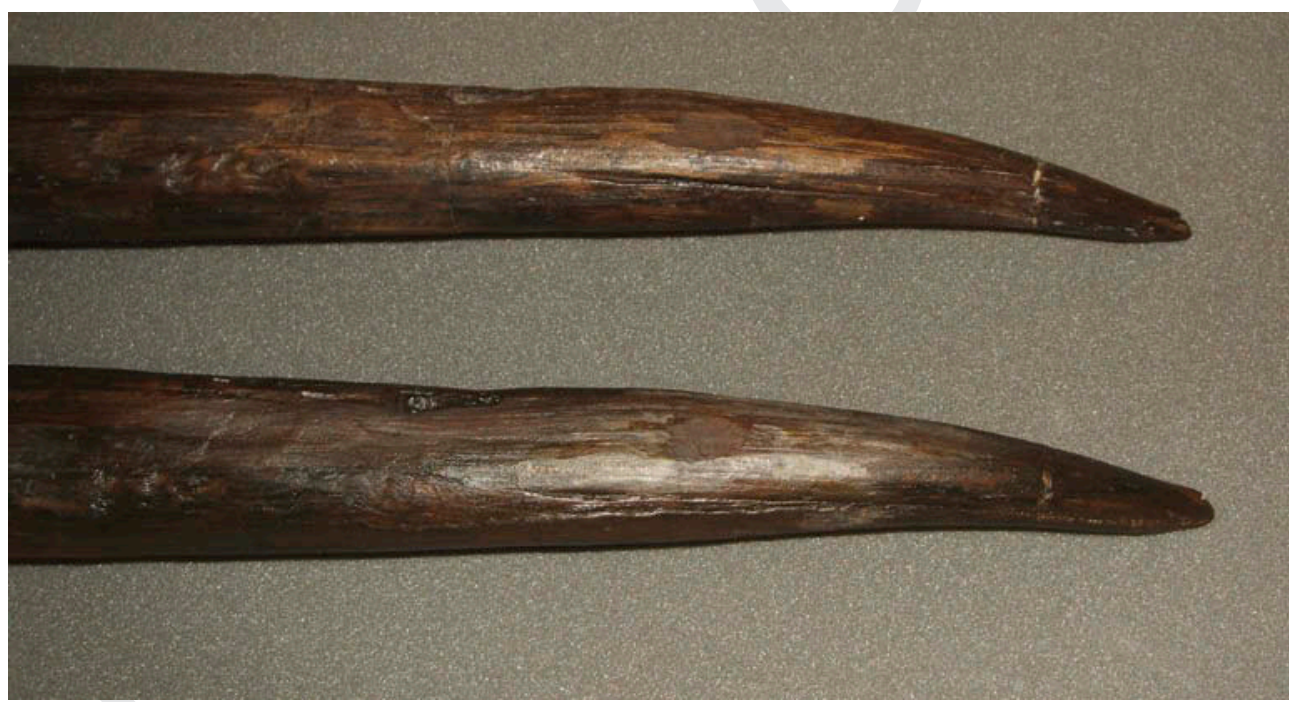

ILLUS. 6 The proximal end of the new cast (top) and spear (bottom). The tool marks were faithfully reproduced by the cast. (Photograph by author)

and the two halves aligned. The label was adhered to Japanese paper using $5 \%$ Methyl cellulose in deionized water and pressed until dry, when it was placed within a transparent polyester pocket. The spear, cast, mould and master casts were then placed

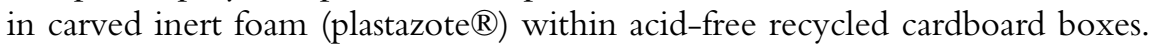




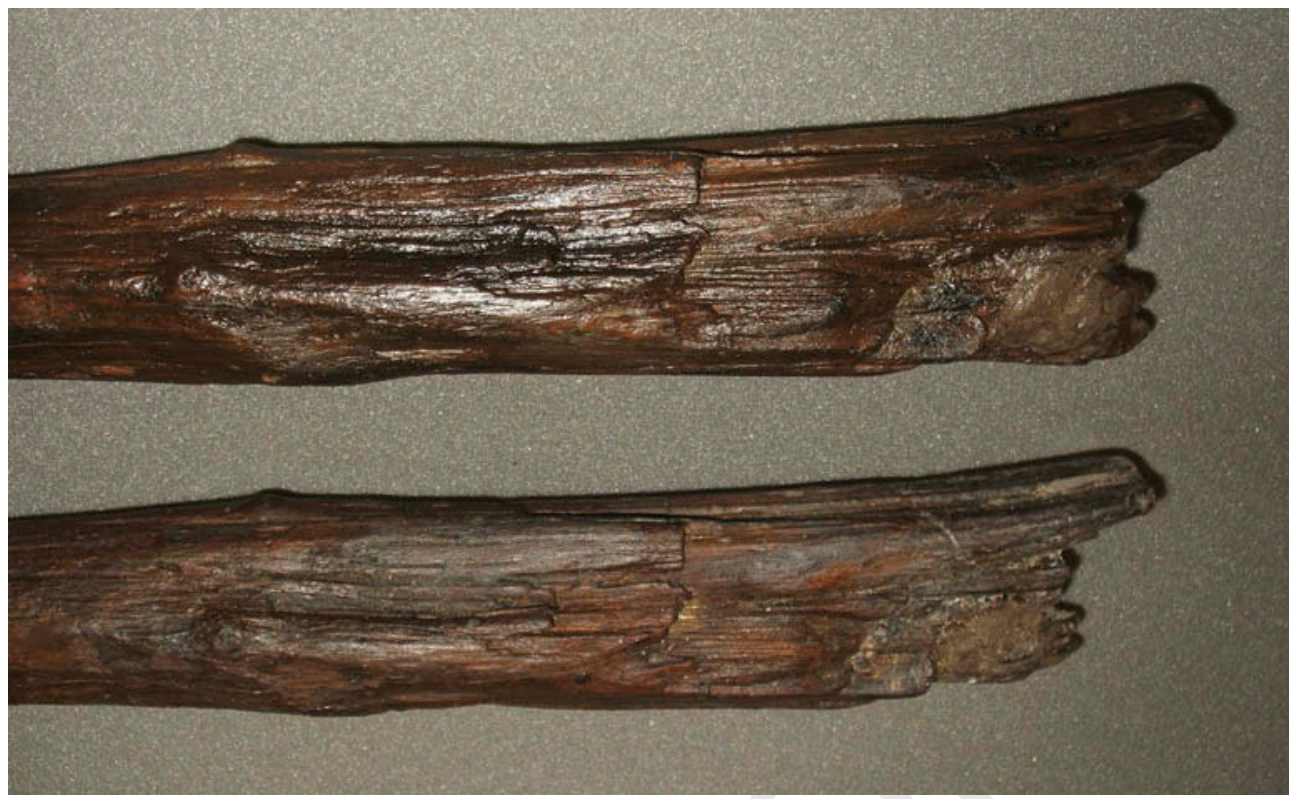

ILLUS. 7 The distal ends of the spear (top) and new cast (bottom). (Photograph by author)

In 2013 the adhesive at the spear's tip was discovered to have failed. Cellulose nitrate adhesive was used in the repair because it had originally been used in 1952 and was found to have caused no damage. This approach also maintained the number of different materials introduced to the spear, additional chemicals could jeopardize future analysis or react with the existing mixture in adverse ways. As a result of these methods, the enduring value of this artefact was recognised in the aforementioned display of the artefact within the NHM's 'One Million Years of the Human Story' exhibition in 20I4.

\section{CONCLUSION}

Hominins are biologically ill-adapted as predators and weapons redress this imbalance (Churchill I993, II): tools have allowed a range of early hominin species to expand their ecological niches, become adaptive to change and manage their environment. The evolution of tool use is therefore an extremely evocative iste and important issue.

The interpretation of the Clacton spear has changed over the last one hundred years following trends in Palaeolithic research. The authenticity of many stone tools has been doubted (Stringer 2006, 42) but the Clacton spear has an advantage over these because it was unquestionably worked. Although it is still dismissed by some authors (Villa and Lenoir 2009, 70) as having been collected outside of an archaeological context, it is most recently interpreted as evidence of skill and the ability to plan, even without the presence of associated human remains to DO ve ineonelusively the Clacton spear's makers' cranial capacity. The Clacton artefact is likely to be a thrusting spear and therefore is evidence of hunting $400 \mathrm{ka}$, probably by a co-operative style. A thrusting 
spear should not be seen as a less important weapon than a javelin, since it is likely to imply co-operative hunting, not to mention extreme intrepidity.

Many aspects of the spear require further investigation, such as the cleft tip and evidence for fire use during its manufacture. Meanwhile, hafting evidence (bulbar thinning, impact scars, adhesive residues and diagnostic microwear) need to be revisited in Clactonian stone tool assemblages. If this evidence is found, the assumed connection between composite tool creation, evolution of the frontal lobe, and the development of speech (Lombard 2005, 297) would therefore have to be revisited. Preservation of the spear continues to be important for continuing Palaeolithic research, and an understanding of its treatment history, along with the physical and chemical changes that have occurred, is essential if this future research is to be informed and valid.

The treatment of the Clacton spear undertaken in 1952 was not entirely successful in preserving shape, but compares well with the results of contemporary treatments, and the valuable tool marks have survived. If deteriorated waterlogged wood is allowed to dry out without treatment, the volumetric loss can exceed $70 \%$ (Barbour I984) and associated distortion and loss of surface detail can be devastating. If the spear had been left in glycerine until modern techniques could have been performed, then it is possible that shrinkage and warping would not have occurred, but it has been handled by many individuals over the past hundred years and potential deterioration could have been far worse as glycerine does not increase mechanical strength. Although a great deal of uncertainty still surrounds the treatment of the Clacton spear, some of its history has been pieced together by researching notes, measurements and images. It exemplifies the importance of recording condition and treatments and its recent replication, new digital images and sketches hope to add to its story. The request to straighten the Clacton spear has been rejected, with agreement from stakeholders (curatorial staff and researchers). Reversing the previous treatments and attempts to re-shape the artefact are considered to be not only unethical but would also pose too much risk to the remaining information.

Lower Palaeolithic worked wood is underrepresented in the archaeological record, so it is still extremely important to preserve the Clacton spear. Preservation of the spear with minimal intervention is essential to allow future analysis. Re-evaluation, reexamination and comparison of evidence from new techniques is endemic to the discipline of Lower Palaeolithic research and the Clacton spear holds further revelations waiting to be discovered.

\section{A CKNOWLEDGEMENTS}

Many thanks to individuals at the Natural History Museum (London): Harriet Campbell Longley of Libraries and Archives, for tracking down so many obscure texts amazingly quickly; Mark Lewis, Chris Stringer and Nick Ashton for help with the text; Efstratia Verveniotou for the most recent repair; Lorraine Cornish for advice on moulding and casting techniques; Robert Kruszynski and Chris Stringer for facilitating access to the artefact and sourcing old documents; Derek Adams, Kevin Webb and Paul Lund for turning the $\mathrm{x}$-radiograph and transparency into digital images; Monique Pullan and Sylvie Seaton at the British Museum, who searched for the original documentation; and the anonymous reviewers for helpful comments on the draft manuscript. 


\section{B IB LIO GR A P HY}

Albright, A. B. I966. The preservation of small waterlogged wood specimens with Polyethylene glycol, Curator 9, 3

Anon. igi i, May io ${ }^{\text {th }}$. Proc. Geol. Soc., 67, xcix

Applebaum, B. 1987. Criteria for treatment: reversibility, J. Am. Inst. Conserv., 26, 65-73

Ashton, N., Lewis, S., Parfitt, S., Candy, I., Keen, D., Kemp, R., Penkman, K., Thomas, G., Whittaker, J. And White, W. 2005. Excavations at the Lower Palaeolithic site at Elveden, Suffolk, UK, Proc. Prehist. Soc., 7I, I-6I

BAKER, H. I975. Early work on the conservation of waterlogged wood in the UK, in W. A. Oddy (ed.) Problems in the Conservation of Waterlogged Wood, Maritime Monographs and Reports, I6, 6I-63, London: National Maritime Museum, Greenwich

Balter, M. 20I4. The killing ground: clues from a German coal mine show how early hunters lived, 300,000 years ago, and how their prey died, Science, 344 (6I 88), Io80-I083

BArbour, R. J. I984. The condition and dimensional stabilization of highly deteriorated waterlogged hardwoods, in R. Ramier and M. Colardelle (eds) Waterlogged Wood: Study and Conservation, Proceedings of the $2^{\text {nd }}$ ICOM-CC Working Group on Wet Organic Archaeological Materials Conference, Grenoble 28-31 August 1984, 23-37, Grenoble: CETBGE

Barham, L. 20I3. From Hand to Handle: the First Industrial Revolution, Oxford University Press: Oxford

Blackshaw, S. M. I974. The conservation of writing tablets from Vindolanda Roman fort. Stud. Conserv., I9(4), 244-246

Boettcher, F. L. J. I9i2. Presentation of osseous and horny tissues, Proceedings of the United States National Museum, 4I, 697-705.

Bomford, D. I994. Changing taste in the restoration of paintings in W. A. Oddy (ed.) Restoration: Is it Acceptable? The British Museum Occasional Paper, 99, 33-40, London: The British Museum

Braovac, S. 200i. An Evaluation of the Condition of the Viking Age Collections at the Viking Ship Museum, Internal Report, Oslo: University Museum of Cultural History

Bridgeland, D. R., Field, M. H., Holmes, J. A., McNabb, J., Preece, R. C., Selby, I., Wymer, J. J., Boreham, S., Irving, B. G., Parfitt, S. A. and Stuart, A. J. I999. Middle Pleistocene interglacial Thames-Medway deposits at Clacton-on-Sea, England: reconstruction of the biostratigraphical and environmental context of type Clactonian Palaeolithic industry. Quaternary Sci. Rev. I8, I09-I46.

Brunning, R., Watson, J., Allen, S., Bamforth, M., Coles, B., Darrah, R., Gdaniec, K., Krawiec, K., Last, J., Lobb, M., Nayling, N., Stallibrass, S., Spriggs, J., Tyers, C. and Williams, J. 20 io Waterlogged Wood: Guidelines on the Recording, Sampling, Conservation and Curation of Waterlogged Wood, London: English Heritage and DeckersSnoeck, Belgium. https://www.english-heritage.org.uk/publications/waterlogged-wood/waterlogged-wood.pdf

CAC-ACCR 2000. Code of Ethics and Guidance for Practice. 3rd ed. <http://www.cac-accr.ca/pdf/ecode. pdf $>$ (Accessed I9 July 20I I)

Caple, C. 200o. Conservation Skills: Judgement, Method and Decision Making, London: Routledge

Chaumat, G. Q., Tran, K., Perre, C. and Lumia, G. I998. Trials of shape recovering from collapsed waterlogged wood by treatment with $\mathrm{CO}_{2}$ supercritical fluid, in C. Bonnot-Diconne, X. Hiiron, Q. Khôi Tran, P. Hoffman (eds), Proceedings of the $7^{\text {th }}$ ICOM-CC working group on wet organic archaeological materials conference, Grenoble, France (1998), I 37-I42, Grenoble: Arc-Nucléart

Christensen, B. B. I97I. Developments in the treatment of waterlogged wood in the National Museum of Denmark during the years I962-I969', in G. Thomson (ed.), Conservation of Wooden Objects: Preprints of the Contributions to the New York Conference on Conservation of Stone and Wooden Objects 7-I3 June 1970, $2^{\text {nd }}$ Edition, Volume 2, 27-37, London: The International Institute for Conservation of Historic and Artistic Works

Churchill, S. E. I993. Weapon technology, prey size selection and hunting methods in modern huntergatherers, in G. M. Peterkin, H. M. Bricker and P. Mellars (eds), Hunting and Animal Exploitation in the later Palaeolithic and Mesolithic of Eurasia, II-24, Washington, D.C.: American Anthropological Association

Churchill, S. E. And Rhodes, J. A. 2009. The evolution of the human capacity for 'killing at a distance': the human fossil evidence for the evolution of projectile weaponry, in Hublin and Richards, $20 \mathrm{I}-2 \mathrm{IO}$ 
Crawford, O. G. S. I92 I. Man and his past, London: Oxford University Press

Crowley, I. 20IO. Histology and cytology, <http://www.irvingcrowley.com/cls/hist.htm> (I I July 20IO)

Dennel, R. I997. 'The world's oldest spears'. Nature, 385, 767-768.

Dewolf, H 2007. Personal communication. Texas A\&M University, USA.

ECCO 2008. Terminology to characterize the conservation of tangible cultural heritage: resolution to be submitted to the ICOM-CC membership on the occasion of the XVth Triennial Conference, New Delhi, 22-26 September 2008, European Federation of Conservator-Restorers' Organisations.

Elder, A S, G Madsen, C Brown, C Herbel, C Collins, S Whelan, C Wenz, S Alderson and L Kronthal 1997. Adhesives and consolidants in geological and paleontological conservation: a wall chart, SPNHC Leaflets: A Technical Publication Series of the Society for the Preservation of Natural History Collections.

Favaro, M., Simon, S., Menichelli, C., Fassina, V. and Vigato, P. A. 2005. 'The four virtues of the Porta della Carta, Ducal Palace, Venice'. Stud. Conserv. 50, I09-I27.

Freund, M, R Ceikos, S Keszthelyi And G Y Mozes, I982. Paraffin products: properties, technologies, applications. Elsevier, Amsterdam

Goodwin, M B AND D S Chaney, I994. 'Molding and casting: techniques and materials', in Vertebrate palaeontological techniques: volume 1 (ed P Leiggi and P May) Cambridge University Press, Cambridge, $235-27 \mathrm{I}$.

Grattan, D. W., I982. A practical comparative study of several treatments for waterlogged wood, Stud. Conserv. 27(3), I24-I36.

DE Guichen, G 2007. 'Forbes Prize lecture: a common definition of conservation and restoration: agree or disagree, but we are living in the tower of babel', Stud. Conserv. 52, 69-73.

Hamilton, D L 2007. Personal communication. Texas A\&M University, USA

Hartin, D. D. I990. 'An Historical Introduction to Conservation'. in Shared Responsibility: Proceedings of a Seminar for Curators and Conservators. (ed B. A. Ramsay-Jolicoeur and I. N. M. Wainwright) Ottawa: National Gallery of Canada, 30-38.

Hoadley, R. B. I978. The dimensional response to wood to variations in relative humidity, in N. S. Brommelle, A. Moncrieff and P. Smith (eds) Conservation of Wood in Paintings and the Decorative Arts, I-6, London: Preprints of the contributions of the Oxford congress I7-23 September I978, IIC

Hoffman, P. I986. On the stabilization of waterlogged oakwood with PEG II: designing a two-step treatment for multi-quality timbers. Stud. Conserv., 3I(3), I03-II3

Hoffman P. and Blanchette, R. I997. The conservation of a fossil tree trunk, Stud. Conserv., 42(2), 74-82

Horie, C. V. I987. Materials for conservation: organic consolidants, adhesives and coatings. London: Butterworths

Hublin, J.-J. and Richards, M. P. (eds) The Evolution of Hominin Diets: Integrating Approaches to the Study of Palaeolithic Subsistence, Vertebrate Paleobiology and Paleoanthropology Series, 59-85, New York: Springer

DE Jong, J I979. The deterioration of waterlogged wood and its protection in the soil, in L. H. de VriesZuiderbaan (ed.) Conservation of Waterlogged Wood: International Symposium on the Conservation of Waterlogged Wood, Amsterdam 24-28 September 1979, 3 I-4O, The Hague: Netherlands National Commission for UNESCO

Jordan, P. I999. Neanderthal: Neanderthal Man and the Story of Human Origins, Stroud: Sutton

Jover, A. I994. The application of PEG 4000 for the preservation of Palaeolithic wooden artefacts, Stud. Conserv., 39(3), I93-98

Kouwenhoven, A. P. I997. World's oldest spears, Archaeol., 50(3), http://www.archive.archaeology.org/ 9705/newsbriefs/spears.html Accessed Io May 2014

Kavvouras, P. K., Kostarelou, C., Zisi, A., Petrou, M. and Moraitou, G. 20o9. Use of silanolterminated polydimethyl-siloxane in the conservation of waterlogged archaeological wood, Stud. Conserv., 54, 65-76

Kaye, B. D., Cole-Hamilton, J. and Morphet, K. 2000. Supercritical drying: a new method for conserving waterlogged archaeological materials, Stud. Conserv., 45(4), 233-52

Kazanskaya, S. Y. and Nikitina, K. F. i984. On the conservation of waterlogged degraded wood by a method worked out in Minsk, in R. Ramier and M Colardelle (eds) Waterlogged Wood: Study and Conservation, Proceedings of the $2^{\text {nd }}$ ICOM-CC Working Group on Wet Organic Archaeological Materials Conference, Grenoble 28-3 I August 1984. I39-I46, Grenoble: CETBGE

Kennedy, A. and Ross Pennington, E. R. 20i4. Conservation of chemically degraded waterlogged wood with sugars, Stud. Conserv., 59(3), I94-20 I 
Kouwenhoven, A. P. I997. World's Oldest Spears. Archaeology, 50(3), <http://www.archive.archaeology. org/9705/newsbriefs/spears.html> (Io May 20I4)

Lombard, M. 2005. Evidence of hunting and hafting during the Middle Stone Age at Sibidu Cave, KwaZuluNatal, South Africa: a multianalytical approach, J. Human Evolution, 48(3), 279-300

Lucas, A I943. Notes on work done on some of the objects from the tomb of Tutankhamun. Unpublished. London: British Library

Madsen, H B, I Meyer and T.Jackson 200i. Conservation of waterlogged wood: an obsolete method, in A. Oddy and S. Smith (eds) Past Practice, Future Prospects, 33-38, Occasional Paper, (4), London: British Museum

Masschelein-Kleiner, L.I985. Ancient Binding Media, Varnishes and Adhesives, Rome: ICCROM

Matsuda, T. I985. On reproducing the shape of the tissues of the dried and shrunk waterlogged wood for the identification of its species, in R. Ramier and M Colardelle (eds) Waterlogged Wood: Study and Conservation, Proceedings of the $2^{\text {nd }}$ ICOM-CC Working Group on Wet Organic Archaeological Materials Conference, Grenoble 28-3 I August I984. I39-I46, Grenoble: CETBGE

McNabi, J. I989. Sticks and stones: a possible experimental solution to the question of how the Clacton spear point was made, Proc. Prehist. Soc., 55, 25 I-7I

McNabb, J. 2007. The British Lower Palaeolithic: stones in contention, Routledge, Abingdon

McNabb, J. and Ashton, N. i995. Thoughtful flakers, Cambridge Archaeol. J. , 5, 289-298

Mhlongo, F. M., Luyt, A. S. And van Sittert, C. G. C. E. 200I. Effect of cross-linking on the thermal stability and molar mass distribution of paraffin waxes, Polymer Degradation and Stability, 73(I), I 5 I-55

Mithen, S. I994. Technology and society during the Middle Pleistocene: hominid group size, social learning and industrial variability, Cambridge Archaeol. J., 4, 3-32

Movins, H. I950. A wooden spear of third interglacial age from lower Saxony, Southwestern J. Anthropol., 6, I39-I 42 .

Moffett, D. L. I996. Wax coatings on ethnographic metal objects: justifications for allowing a tradition to wane, J. Amer. Inst. Conserv., 35(I), I-7

Mühlethaler, B i973. Conservation of Waterlogged Wood and Wet Leather, Paris: Eyrolles

Müller-Beck, H. and HaAs, A. I960. A method for wood preservation using Arigal C, Stud. Conserv., 5(4), I 5 O-I 58

Munnikendam, R. A. i967. Conservation of waterlogged wood using radiation polymerisation. Stud. Conserv., I2(2), 70-75

Munnikendam, R. A. I973. The conservation of waterlogged wood with Glycol methacrylate, Stud. Conserv., I8(2), 97-99

Muñoz Viñas, M. 2005. Contemporary Theory of Conservation, Oxford: Butterworth Heinemann

MuÑoz Viñas, S. 2009. Beyond authenticity', in E. Hermens and T. Fiske (eds) Art: Conservation and Authenticities - Material, Concept, Context, 33-38, London: Archetype Publications

Nakhla, S. M. I986. A comparative study of resins for the consolidation of wooden objects, Stud. Conserv., 3I(I), 38-44

Oakley, K. and Leakey, M. I937. Report on excavations at Jaywick Sands, Essex (I934), with some observations on the Clactonian Industry, and on the fauna and geological significance of the Clacton Channel, Proc Prehist. Soc., 3(2), 2 I 7-260

Oakley, K. P. P. Andrews, Keeley, L. H. and Clark, J. D. i977. A reappraisal of the Clacton spearpoint, Proc. Prehist. Soc., 43, I3-30

OdDy, A I994. Restoration: is it acceptable? in A. Oddy (ed.), Restoration: is it acceptable? British Museum Occasional Paper, 99, 3-8, London: British Museum

Ohel, M. Y. I979. The Clactonian: an independent complex or an integral part of the Acheulean?' Current Anthropol., 20, 685-7I 3

Organ, R. M. I959. Carbowax and other materials in the treatment of water-logged Palaeolithic wood, Stud. Conserv., 4(3),96-I05

Organ, R. M. I963. Consolidation of fragile metallic objects, in G. Thomson (eds) Recent Advances in Conservation, I28-33, London: Butterworths

Padfield, T. I992. Conservation of Waterlogged Wood, <http://www.natmus.dk/cons/x/ww/wwi.htm> (22 July 20IO).

Paulke, M. 2003. Die Bergung zweier frühneuzeitlicher Holzfragmente mittels Paraffin, Beiträge zur Erhaltung von Kunst- und Kulturgut, I, 94-96

Pearce, S. I990. Archaeological Curatorship, Leicester: Leicester University Press 
Perchenko, A. A. And Serov, V. V. i980. Acceleration of paraffin wax oxidation by the use of molecular oxygen, Chemistry and Technology of Fuels and Oils, I6(4), I3-I5

Pitts, M. And Roberts, M. I997. Fairweather Eden: life in Britain half a million years ago as revealed by the excavations at Boxgrove. Century, London.

Pye, E. And Sully, D. 2007. Evolving challenges, developing skills, The Conservator, 30, I9-38

Rhodes, J. A. And Churchill, S. E. 2009. Throwing in the Middle and Upper Paleolithic: inferences from an analysis of humeral retroversion, J. Human Evolution, 56(I), I-IO

Rice, J. W. I966. An heirloom patchwork quilt and its conservation problems, Stud. Conserv., II(I), I-7

Rigby, J. K. and Clark, D. L. I965. Casting and moulding, in B. Kumel and D. Raup (eds) Handbook of Palaeontological Techniques, 389-4I3, San Francisco and London: W H Freeman and Company

Rixon, A E 1976. Fossil Animal Remains: their Preparation and conservation, Athelone Press, London, 8

Roebroeks, W. 2008. Time for the Middle to Upper Palaeolithic transition in Europe, J. Human Evolution, 55, 918-926.

Rosenqvist, A. I959a. The stabilizing of wood found in the Viking ship of Oseberg: Part II. Stud. Conserv., 4(2), 62-72

Rosenqvist, A i959b. The stabilizing of wood found in the Viking ship of Oseberg: Part I, Stud. Conserv., 4(I), I $3-22$

Selwitz, C I988. Cellulose Nitrate in Conservation. Research in Conservation 2, The Getty Conservation Institute, Los Angeles

Schaffer, E. I97i. Consolidation of softwood artefacts. Stud. Conserv., I6, i Io-I I 3

Schmitt, D., Churchill, S. E. And Hylander, W. L. 2003. Experimental evidence concerning spear use in Neanderthals and early modern humans, J. Archaeol. Sci., 30(I), IO5

SChNell, U. AND Jensen, P. 2007. Determination of maximum freeze drying temperature for PEG-impregnated archaeological wood, Stud. Conserv., 5, 50-58

Scott, B. 20I . Becoming Neanderthals: the Earlier British Middle Palaeolithic, Oxbow Books: Oxford and Oakville

Shashoua, Y., Bradley, S. M. and Daniels, V. D. I992. Degradation of cellulose nitrate adhesive, Stud. Conserv., 37(2), I I 3 -I I9

Shaw, C. N., Hofman, C. L., Petraglia, M. D., Stock, J. T. and Gottschall, J. S. 20i2. Neandertal humeri may reflect adaptation to scraping tasks, but not spear thrusting, PLoS ONE, 7(7), I-7

SheA, J. J. 2009. The impact of projectile weaponry on late Pleistocene hominin evolution, in Hublin and Richards, I89-I99

ŠmůnkovÁ, E., ŠmejkalovÁ, Z. ANd Zelinger, J. I983. Consolidation of wood by the method of monomer polymerization in the object, Stud. Conserv., 28(3), I33-I 44

Sмith, G. M. 20I2. Hominin-carnivore interaction at the Lower Palaeolithic site of Boxgrove, UK, $J$. Taphonomy, I0 (3-4), 373-394

Snethlage R. and Wendler, E. 2000. Chemical conservation of stone structures, in G. Bellussi, M. Bohnet, J. Bus, K. Drauz, H. Greim, K.Jäckel, U. Karst, A. Kleemann, G. Kreysa, T. Laird, W. Meier, E. Ottow, M. Röper, J. Scholtz, K. Sundmacher, R. Ulber, U. Wietelmann (eds) Ullman's Encyclopedia of Industrial Chemistry, Oxford: Wiley-VCH.

Stark, B. L. I976. Waterlogged wood preservation with Polyethylene glycol, Stud. Conserv., 2I(3), I $54-$ I 58

Stringer, C. 2006. Homo Britannicus, London: Allen Lane

Stringer, C. 20II. The changing landscapes of the earliest human occupation of Britain and Europe, Dev. Quat. Sci., I4, I-IO

Stringer, C. and Gamble, C. I995. In Search of Neanderthals: Solving the Puzzle of Human Origins, New York: Thames and Hudson

Thieme, H. I997. Lower Palaeolithic hunting spears from Germany, Nature 385, 807-8 Io

Thieme, H. I999. Lower Palaeolithic throwing spears and other wooden implements from Schöningen, in $\mathrm{H}$. Ullrich (ed.) Hominid Evolution: Lifestyles and Survival Strategies, 383-395, Archaea: Gelsenkirchen

Thieme, H. 2005. The lower palaeolithic art of hunting: the case of Schöningen I3 II-4, Lower Saxony in C. Gamble and M. PorrGermany (eds) The Hominid Individual in Context: Archaeological Investigations of Lower and Middle Palaeolithic Landscapes, Locales and Artefacts, I I 5-I32, Routledge: London and New York

Tyldesley, J. A. And Bahn, P. G. I983. Use of plants in the European Palaeolithic: a review of the evidence, Quat. Sci. Rev., 2, 53-8I

Tiffany, M and Iwama, B. I994. Cast painting, in P. Leiggi and P. May (ed.) Vertebrate Palaeontological Techniques: Volume 1, 27I-84, Cambridge: Cambridge University Press, Cambridge 
VAN DeR VALL, R. I999. Painful decisions: philosophical considerations on a decision-making model, in I. Hummelen and D. Sille (eds) Modern Art: Who Cares? I96-200, Amersfoort, The Netherlands: Foundation for the Conservation of Modern Art/Netherlands Institute for Cultural Heritage

Villa, P. ANd Lenoir, M. 2009. Hunting and hunting weapons of the Lower and Middle Palaeolithic of Europe, in Hublin and Richards, 59-85

Waguespack, N. M. Surovell, T. A., Denoyer, A., Dallow, A., Savage, A., Hyneman J., and Tapster D., 2009. Making a point: wood- versus stone-tipped projectiles. Antiquity, 83(32 I), 786-800

Walsh, Z., Janeček, E., Hodgrinson, J. T., Sedlmair, J., Koutsioubas, A., Spring, D. R., Welch, M., Hirschmugl, C. J., Toprakcioglu, C., Nitschke, J. R., Jones, M., and Scherman, O. A., 20 i 4. Multifunctional supramolecular polymer networks as next-generation consolidants for archaeological wood conservation. Proc. Nat. Acad. Sci. United States Amer., III(50), I7743-I7748

Warren, S. H. I922. The Mesvinian Industry of Clacton-on-Sea, Essex, Proc. Prehist. Soc. East Anglia, 3(4), 597-602.

Wenban-Smith, F. F. 20I3. The Ebbsfleet Elephant. Excavations at Southfleet Road, Swanscombe in advance of High Speed 1, 2003-4, Oxford: Oxford Archaeology

Werner, A. E. I96I. Consolidation of fragile objects, Stud. Conserv., 6(4), I33-I35

Lu Allington-Jones, The Conservation Centre, The Natural History Museum, Cromwell Road, London $\mathrm{SW}_{7} 5 \mathrm{BD}$

Email: 1.allington-jones@nhm.ac.uk 